\title{
Why ethical journalists deserve better code
}

As Pacific journalists seek codes of ethics of their own, the new draft Australian code of ethics fails to give journalists and the public confidence. An open and comprehensive process of consultation is needed. The code needs to better protect the right to know.

\section{BY PETER CRONAU}

RARE OUTPOURINGS of praise on the death of ABC Four Corners journalist, Andrew Olle, last year, show that not all journalists are as unpopular as used car sellers. Many in the media are very well respected for the professional and constructive role they play in keeping the public informed.

However, the ethics of journalists probably vary about as much as they do in the general population. To try to improve the standing of journalists in the public's eye and to avoid some of the extremes of journalistic excess, the Australian journalists' union - the Media Entertainment and Arts Alliance last year released a proposed new code of ethics. (See panel).

Most journalists would agree that improvements to the old voluntary code were overdue. There are indeed several improvements over the old code in the proposed draft code. The draft code proposes (Point 5) that journalists be specifically required to use 'pictures and sound' that are 'true and accurate', reflecting the ability of the new digital technology to seamlessly alter material.

Not unreasonably, plagiarism is specifically precluded (Point 6), as is the fabrication of quotes (Point 7). Journalists are to be required to disclose when payment is made for interviews or material (Point 8).

No doubt in a reaction to the notorious Mike Willisee interview of children caught in a seige, the draft code requires 'particular care for the welfare of children in reports involving them' (Point 17).

Most significantly however, the draft code also weakens some of the better elements of the current code. 
It is worrying that reference to 'the public's right to information' has disappeared from the proposed draft code.

The current code states (Preamble): Respect for truth and the public's right to information are overriding principles for all journalists.

The draft code states (Preamble): 'Journalists describe society to itself. They seek truth. They convey information, ideas, opinions ... They search, disclose, record, question, entertain, suggest and remember', and so on.

The draft code refers to this as 'these public responsibilities'. But is itreally suggesting to "entertain" is a public responsibility? And what was wrong with the current wording?

The International Federation of Journalists - of which the MEAA is a member - states in its code that 'Respect for truth and for the right of thepublic to truth is the first duty of the journalist'.

In times when, among other things, the 'national interest' is defined as having good trade relations with our neighbours, the MEAA's proposed code needs such an unambiguous statement.

$\square$ A cornerstone of ethical journalism is that journalists should always identify themselves as journalists when interviewing. Of course it could be argued that this could be breached in major matters of extraordinary public interest.

The current code (Point 8) states journalists 'shall identify themselves and their employers before obtaining any interview for publication or broadcast'. The new draft code of ethics (Point 14, Sentence 4) eliminates this most crucial element. It seems the only time that journalists are now to be required to 'interview only with informed consent' are 'at times of grief or trauma'.

Under the current code (Point 9), journalists used to 'have the right to resist compulsion to intrude' in matters of grief and personal privacy.

While the draft code (Point 14) says 'never to harass' nor 'exploit vulnerability', the words 'right to resist compulsion' have been removed.

$\square$ The code on guarding against commercial influence is weakened. Instead of "not allow[ing] advertising or commercial considerations to influence them in their professional duties' (Point 6), journalists will only need to 'Guard against advertising or commercial considerations improperly influencing [their] journalism' (Point 12). And then it has it both ways and says that where it has 'improperly influence[d] journalism', the journalist should 'disclose' it.

$\square$ The section on keeping sources confidential is fatally weakened. The current code states (Point 3): In all circumstances they shall respect all confidences. But under the new draft code (Point 19) journalists will only be required to 'keep confidences given in good faith'. And anonymity will only be given to a source after 'considering the source's motive'. If, for example, the 


\section{PETER CRONAU}

motive of some whistleblower on an issue of public safety is revenge for, say, dismissal, is it suggested that their anonymity should not be preserved?

The making of corrections for errors may now be less likely. From previously under the current code (Point 10) journalists 'do[ing] theirutmost to correct' errors, they will only need to 'Urge the fair correction of errors' (Point $3)$.

$\square$ A crucial flaw in the new draft code is the omission of ethical guidelines for reporting Aboriginal and Torres Strait Islander affairs, despite recommendations to this effect from the Royal Commission into Aboriginal Deaths in Custody. Journalists and their editors and producers need reminding about such matters as expectations in regard to naming of deceased Aborigines, protocols for entering Aboriginal communities, seeking Aboriginal spokespersons, and so forth. The new draft code fails Aboriginal people absolutely.

The wide public praise for Andrew Olle shows that the public respects ethical behaviour from its journalists. The language of the draft code of ethics fails to insist upon ethical behaviour in journalists - 'make efforts', 'urge', 'avoid', being some of the words it uses.

It is only in the most extraordinary cases that journalists ought to consider breaching the code, and then they should be prepared to explain and justify their actions when this has happened.

Of course some journalists' unscrupulous employers - or their editors or producers - may request them to act in unethical ways against the public interest. It is in this instance that the journalist needs the backing of a strong code, and a strong union. The draft code has given up on some very crucial issues without a fight.

Overall the proposed draft fails to deliver a code in which journalists andthe putlic can have confidence. What is drastically needed is an open and comprehensive process of consultation with journalists and the public torefine the draft code.

If a voluntary code fails to advance ethical behaviour by journalists, it strengthens the arguments of those who may advocate heavy-handed government intervention. The draft code of ethics needs to be strengthened to better protect journalists, the public, and the public's right to know.

$\square$ Peter Cronau is a writer on social and regional issues, a member of the PJR editorial board, and is editorial director of the Australian Centre for Independent Journalism (ACIJ), at the University of Technology, Sydney. This article was originally published in Uni Tavur on 26 April 1996.

bfmedia@peg.apc.org 